\title{
Proceeding
}

Supplementary Issue: Spring Conferences of Sports Science. Costa Blanca Sports Science Week, 26-28 April 2018. Calpe. Alicante, Spain

\section{An investigation of drugs abuse in sport performance}

\author{
FILOMENA MAZZEO1, GAETANO RAIOLA ${ }^{2}$ \\ ${ }^{1}$ Department of Science and Technology University of Naples "Parthenope", Naples, Italy \\ ${ }^{2}$ Department of Human, Philosophical and Education Sciences, University of Salerno, Italy
}

\begin{abstract}
Doping in performance sport is a complex and controversial issues. The secrecy that characterizes it hinders the implementation of epidemiological investigations. It involves the entire society. Moreover, the forces that conspire behind doping have always been able not only to identify new substances and new methods but also to steal the new scientific discoveries aimed at the treatment of diseases, for their illegal purposes. The fight against doping has had a strong push, in 2004, with the birth of the first World Anti-doping Code drafted by WADA. The laboratories, the Code, the Biological Passport and the ADAMS are important tools for the fight against doping. The aim study is to show the data relating to the consumption of drugs from 2003 to 2017. A number of the commonly used substances have been discussed and their risks and side effects reviewed. Key words: DOPING CONTROLS, DRUGS, SPORT, ANALYSIS, ILLICIT SUBSTANCES, LEGISLATION.
\end{abstract}

\section{Cite this article as:}

Mazzeo, F., \& Raiola, G. (2018). An investigation of drugs abuse in sport performance. Journal of Human Sport and Exercise, 13(2proc), S309-S319. doi:https://doi.org/10.14198/jhse.2018.13.Proc2.15

Corresponding author. Department of Human, Philosophical and Education Sciences, University of Salerno, Italy. http://orcid.org/0000-0002-7659-1674

E-mail: raiolagaetano@libero.it

Supplementary Issue: Spring Conferences of Sports Science. Costa Blanca Sports Science Week, 26-28 April 2018. Calpe. Alicante, Spain.

JOURNAL OF HUMAN SPORT \& EXERCISE ISSN 1988-5202

(c) Faculty of Education. University of Alicante

doi: 10.14198/jhse.2018.13.Proc2.15 


\section{INTRODUCTION}

Sport performance today is the results of many factors, who playing an important role in the athletes' results (Mazzeo et al. 2016; Sjöqvist et al, 2008; Calatayud et al. 2007).

Moreover, Intensity training, talent, and an adequate diet represent the crucial factors for the success of athletes (Mazzeo et al 2016). Expert on performance sport define performance sport as the results a specific activity, usually competitions, as an extent to which a motor task limited by rules of a given sports discipline is accomplished (Altavilla et al, 2017, Raiola, 2017, Raiola, D'Isanto 2017, Tiziana et al, 2017, D'Isanto, 2016, Montesano et al, 2013).

The use of drugs to enhance performance in sports has certainly occurred since the time of the original Olympic Games [from 776 to $393 \mathrm{BC}$ ]. The derivation of the word 'doping' has origin to the Dutch word 'doop,' which is a viscous opium juice, the drug of choice of the ancient Greeks (Martínez-Sanz et al. 2017; Mazzeo \& Volpe, 2016).

It seems that the term doping is derived from an ancient African dialect "doop" as meaning a mixture or a potion. The willingness to compromise the performance involved, as victims, even the animals. The Greek wrestlers and the Roman gladiators attempted to improve their own performance by taking mixtures of various types of plants or by eating sheep's testicles (Dilger et al, 2007). Doping means athletes taking illegal substances to improve their performances.

Moreover, doping is a complex phenomenon analysing the vast variety of substances, supplied through both legal and illegal trading routes and the extensive connections between the people involved in the network (Esseiva et al., 2007).

Drug abuse is one of the biggest problems in sports. It involves the repeated and excessive use of chemical substances to realize a certain effect. It can also be referred to as substance abuse or doping (Mazzeo et al, 2016).

Doping is increasingly a matter that concerns the whole society: it involves not only elite athletes but amateurs too, their friends and relatives, the medical staff, managers, chemists, biologists and pharmacists, pharmaceutical industries, clandestine laboratories and criminal organizations (Marclay et al., 2013; Mazzeo et al. 2017). The combination of sport and doping arouses negative reactions. An athlete who takes drugs to win is guilty of fraud and all the stakeholders immediately dissociate them from a sport not fair: the sponsors, for example, rescind their endorsements (Presidenza del Consiglio dei Ministri, 2010).

During the last 2 decades, progress in deciphering the human gene map as well as the discovery of specific defective genes encoding particular proteins in some serious human diseases have resulted in attempts to treat sick patients with gene therapy (Mazzeo \& Volpe, 2016). There has been large attention on human recombinant proteins which were gene-engineered and produced in vitro (insulin, insulin-like growth factor1, erythropoietin, growth hormone). These substances and methods also became improper tools for dishonest athletes (Santamaria S. et al., 2013). In fact, a new frontier reached by the doping is the use of genes. 
According to the Anti-Doping Agency, substances and methods are banned when they meet at least two of the three following criteria: they improve performance, pose a threat to athlete health, or no respect the spirit of sport (Mazzeo et al. 2016; Santamaria et al. 2013).

\section{The prohibited substances}

The explosive spread of doping has triggered the response of the International Olympic Committee in 1960 (Botrè, 2008). At beginning, the first anti doping test were sporadic and not completely reliable. Fortunately, in 1999, thanks to the creation of the World Anti Doping Agency, it was finally created an organization with the sole purpose to fight this "cancer" of sport and consequently the situation of tests is changed (Dvorak J. et al. 2014; Valkenburg D. et al. 2014).

The World Anti-Doping Agency (WADA) was an international organization, that is established on November 10,1999 with the aim to promote, coordinate, and monitor the fight against doping in sport in all its forms. In 2004, the aforementioned organization has harmonized the rules and regulations governing anti-doping across all sports and all countries for the first time through the issuance of a Code which defines the doping (Kayser B. et al., 2005). In accordance with the WADA Code, doping is the presence of a prohibited substance or its metabolites or markers' banned; the use or the attempted use of a prohibited substances or a prohibited method; the refusing or the failing, without compelling justification, to submit to sample collection; the violation of applicable requirements regarding athlete availability for out-of-competition testing; the tampering or the attempting to tamper with any part of doping control; the possession of prohibited substances and prohibited methods; the trafficking or the attempted trafficking in any prohibited substance or prohibited methods; the administration or the attempted administration to any athlete of any prohibited methods or prohibited substances, or the assisting, the encouraging, the aiding, the abetting, the covering up or any other type of complicity involving an anti-doping rule violation or any attempted anti-doping rule violation.

(WADA, 2017)

The Agency has compiled a list of banned substances and practices that is constantly updated. Now, WADA, for example, has identified more than two hundred banned substances currently divided into 10 classes (including the class S0) and three methods, as you can see in table 1 (Strano Rossi S., et al. 2011).

The most commonly used substances are androgenic agents such as anabolic steroids. (Mazzeo, 2016). These permit athletes to train harder, recover more quickly and build more muscle, but they can lead to kidney damage and increased aggression. Anabolic agents, peptide hormones, growth factors and related substances and mimetics and beta- 2 agonists are assumed in order to increase the muscle mass (Stiegel et al 2010). Moreover, the last two classes of substances and stimulants and the method of manipulation of blood and blood components are useful for increasing of endurance and for increasing of reactivity and aggression, athletes take stimulants, narcotics, cannabinoids, glucocorticosteroids and alcohol (Strano et al, 2011). Moreover, in order to mask the assumption of drug, the athletes take hormone and metabolic modulators and diuretics and masking agents (Table 1).

Table 1. 2017 Wada prohibited substances and methods

Substances and methods prohibited in and out competition

\section{S1 Anabolic agents}

S2 Peptide hormones, growth factors, related substances and mimetics

S3 Beta- 2 agonists 


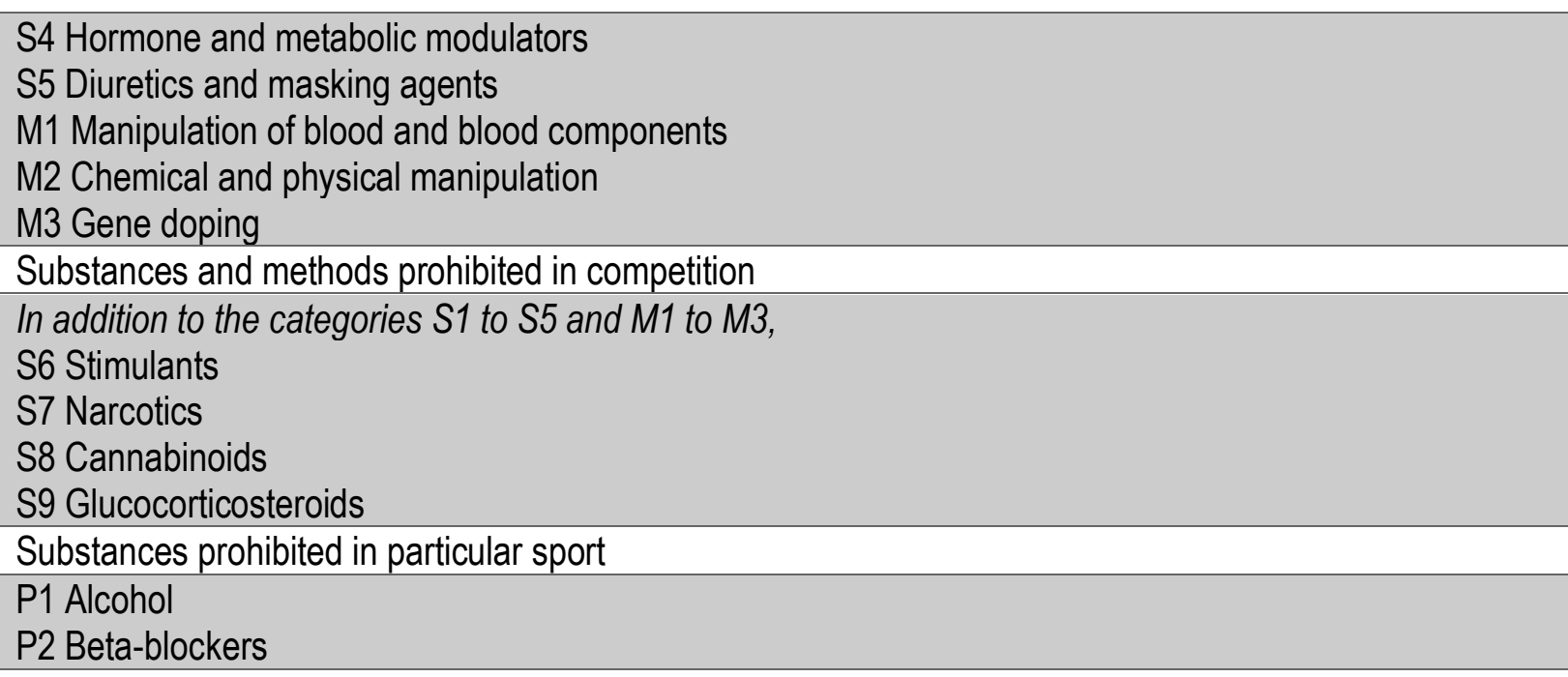

\section{MATERIALS AND METHODS}

This is a descriptive study, consisting of a bibliographic review of the presence of substances/metabolites/markers prohibited by the WADA in the Italian sporting context during the period 2003 -2016. The inclusion criteria were literature search, was performed on PubMed and Scopus database and Italy Anti-doping official website. Data showed are originated from the report commissioned by the Italian Ministry of Health. Indeed, every year -since 2003- anti-doping tests carry out. Perhaps it is possible to know the spread year per year of doping in Italy. The authors have compared the above mentioned data in order to show doping's spread in this period. Table supports the comparison.

\section{RESULTS}

The search strategy retrieved have to know that the prohibited substances and/or the amount of substance prohibited constantly change: some of them have been eliminated over time while others have been added. For example, pseudoephedrine and norephedrine were removed from the list in 2003 but in 2013, the first substance was reintroduced with a different dosage. Local anesthetics and caffeine were eliminated in 2004 (Strano Rossi et al, 2011), even if the substance has been included in the monitoring program of WADA in 2015. Since 2003, the Commission carried out doping tests. The tests collected only urine samples (Badoud et al, 2013; Mazzeo et al. 2017).

Analyzing the consumption of prohibited substances and considered that the control activities of the AntiDoping Commission began in April 2003, in that year there was a high consumption of stimulants equal to 40\%. The lowest percentages are $10.3 \%$ in 2010 and $6.7 \%$ in 2013. Compared with the year 2012, consumption fall by 13 percentage points. The average consumption from 2003 to 2016 is $19.3 \%$.

The cannabis derivatives have a peak of consumption in 2005 and 2007 , respectively, with $42.6 \%$ and $42.3 \%$. Their use in the other years is characterized by ups and downs: it should be noted, indeed, that in 2012 the percentage is $31.8 \%$, while in 2013 is $16.7 \%$. The lowest consumption occurred in 2014 with the $3 \%$. The average consumption is $22.6 \%$. 
Regarding diuretics and masking agents, they have almost a constant trend over the years. The peak is reached in 2014 with $26.7 \%$ and in 2008 it was recoded the lowest percentage: $3,4 \%$. The average consumption of this type of substances is $16.5 \%$.

Anabolic agents experienced a sharp increase in their consumption in 2010 and 2013, respectively with $37.1 \%$ and $35 \%$. The average consumption is $18.4 \% \%$.

Corticosteroids have a peak in 2016 with $21.2 \%$ and the lowest consumption in 2007 with $3.8 \%$. The average consumption is $9.5 \%$.

Hormones and related substances have a low consumption with $2.1 \%$ and spike in consumption in 2008 to $25.4 \%$. The trend in consumption was fluctuating and the average is $10.4 \%$.

Beta-2 agonists have been banned since 2009. Their peak occurred in 2016 with the $9.1 \%$ of consumption and, after a brief decline in 2012 by $1.5 \%$. Its average consumption is $4.2 \%$.

Beta-blockers are irrelevant over the years. There are no data for 2013 and its average fuel consumption is $2.5 \%$.

Another exception should be made for local anesthetics as they were prohibited only in 2003.

Regarding agents with anti-estrogenic activity and narcotics, the consumption has been detected only in few years with low percentage (Table 2, Table 3 ).

Table 2. Consumption of prohibited substances over the years. Breakdown per classes of substances and for years. Values are expressed in percentages. Reference period: 2003-2016

\begin{tabular}{|c|c|c|c|c|c|c|c|c|c|c|c|c|c|c|}
\hline \multirow[t]{2}{*}{$\begin{array}{r}45,00 \% \\
40,00 \% \\
35,00 \% \\
30,00 \% \\
25,00 \% \\
20,00 \% \\
15,00 \% \\
10,00 \% \\
5,00 \% \\
0,00 \%\end{array}$} & 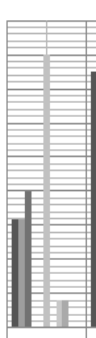 & \begin{tabular}{|l} 
\\
\\
\\
\\
\end{tabular} & \begin{tabular}{|l} 
\\
\\
\\
\\
\end{tabular} & 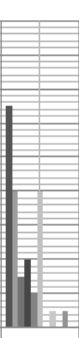 & 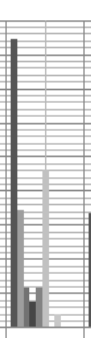 & 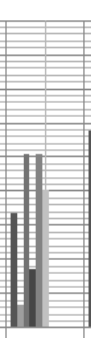 & 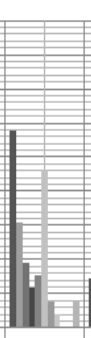 & $\begin{array}{lll} & \\
\end{array}$ & 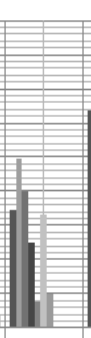 & 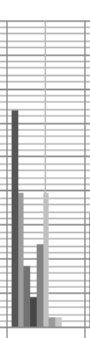 & 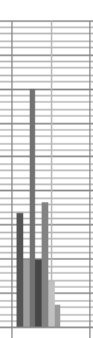 & 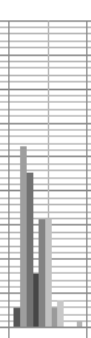 & 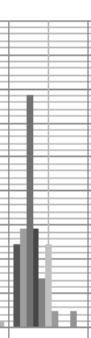 & 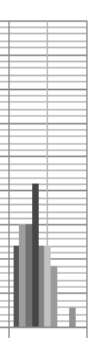 \\
\hline & 2003 & 2004 & 2005 & 2006 & 2007 & 2008 & 2009 & 2010 & 2011 & 2012 & 2013 & 2014 & 2015 & 2016 \\
\hline cannabinoids & $16,00 \%$ & $37,50 \%$ & $42,60 \%$ & $32,50 \%$ & $642,30 \% 1$ & $16,90 \%$ & $28,80 \%$ & $67,20 \% 1$ & $17,30 \%$ & $\$ 1,80 \%$ & $16,70 \%$ & $\% 3,00 \%$ & $12,20 \%$ & $612,10 \%$ \\
\hline diuretics and masking agents & $16,00 \% 1$ & $16,70 \% 1$ & $19,10 \%$ & $20,00 \%$ & $17,30 \%$ & $63,40 \% 1$ & $15,40 \% 1$ & $612,40 \%$ & $24,80 \%$ & $19,70 \%$ & $10,00 \%$ & $26,70 \%$ & $14,60 \%$ & $615,20 \%$ \\
\hline anabolic agents & $20,00 \% 1$ & $10,40 \%$ & $6,40 \%$ & $7,50 \%$ & $5,80 \% 2$ & $25,40 \%$ & $9,60 \%$ & $37,10 \%$ & $20,00 \%$ & $69,00 \%$ & $635,00 \%$ & $22,80 \%$ & $834,10 \%$ & $615,20 \%$ \\
\hline corticosteroids* & & $4,20 \%$ & $6,40 \% 1$ & $10,00 \%$ & $63,80 \%$ & $8,50 \%$ & $5,80 \% 1$ & $14,40 \%$ & $12,50 \%$ & $04,50 \%$ & $610,00 \%$ & $\% 7,90 \%$ & $14,60 \%$ & $021,20 \%$ \\
\hline hormones and related substances & & & $2,10 \%$ & $5,00 \%$ & $5,80 \% 2$ & $25,40 \%$ & $67,70 \% 1$ & $10,30 \%$ & $63,80 \% 1$ & $12,20 \%$ & $18,30 \%$ & $15,80 \%$ & 7,30\% & $612,10 \%$ \\
\hline stimulants & $40,00 \%$ & $29,20 \% 2$ & $21,30 \%$ & $20,00 \%$ & $23,10 \%$ & $20,30 \%$ & $23,10 \%$ & $10,30 \%$ & $16,60 \%$ & $19,70 \%$ & $\% 6,70 \%$ & $15,80 \%$ & $12,20 \%$ & $012,10 \%$ \\
\hline beta-2 agonists $* * *$ & & & & & & & $3,80 \%$ & $6,20 \%$ & $5,00 \%$ & $1,50 \%$ & 6 3,30\% & $3,00 \%$ & $2,40 \%$ & 9,10\% \\
\hline beta-blockers & $4,00 \%$ & $2,10 \%$ & $2,10 \%$ & $2,50 \%$ & $1,90 \%$ & & $2,00 \%$ & & & $1,50 \%$ & & $4,00 \%$ & & \\
\hline local anaesthetics** & $4,00 \%$ & & & & & & & & & & & & & \\
\hline agents with anti-estrogenic activity & & & & $2,50 \%$ & & & & & & & & & $2,40 \%$ & $3,00 \%$ \\
\hline narcotics & & & & & & & $3,80 \%$ & $2,10 \%$ & & & & $1,00 \%$ & & \\
\hline
\end{tabular}

* recognized only since $2004{ }^{* *}$ not prohibited after $2003{ }^{* * *}$ recognized from 2009 
Table 3. Percentage of consumption of prohibited substances over the years. Breakdown per classes of substances. Values are expressed in percentages. Reference period: 2003-2016

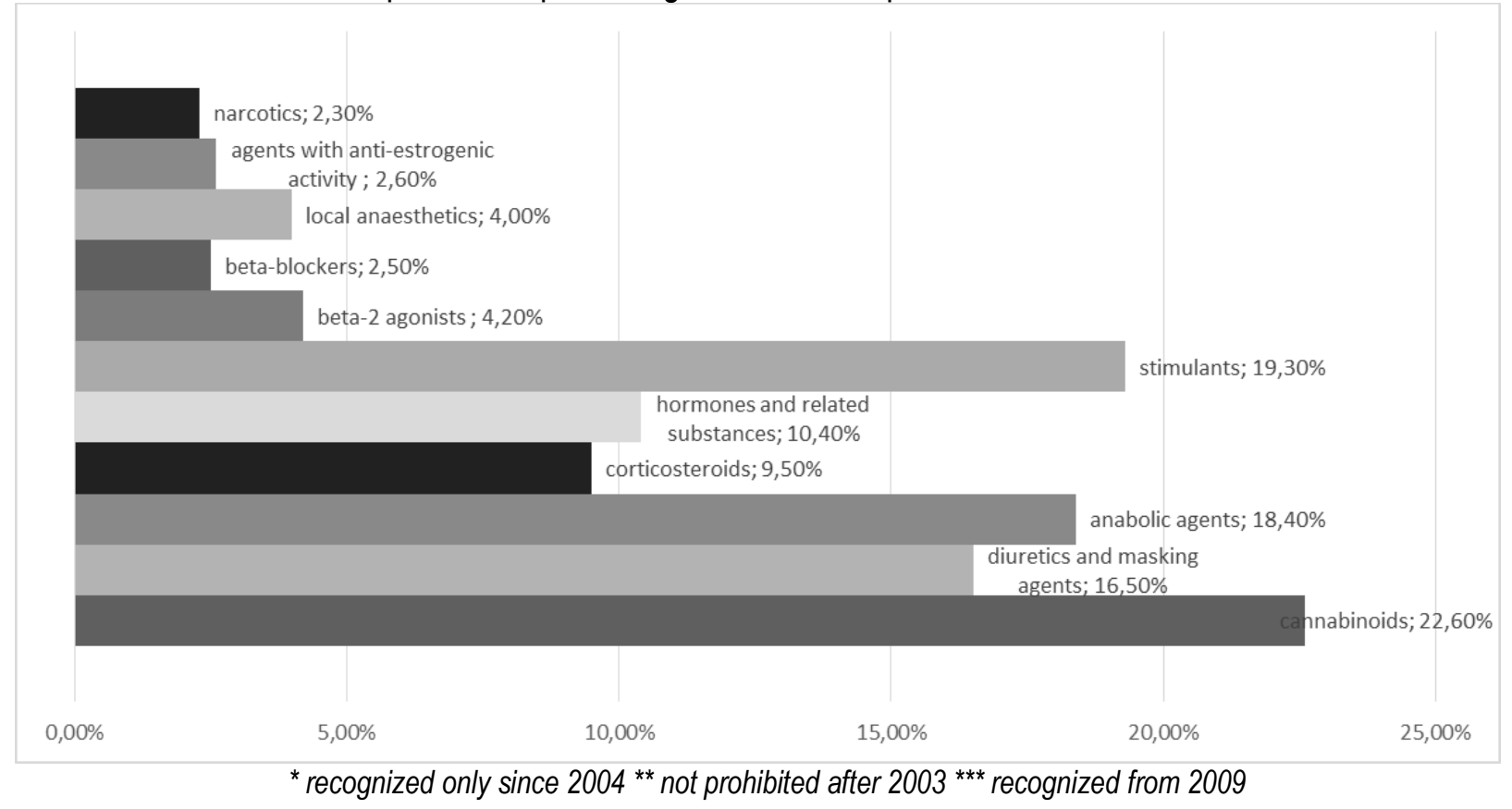

\section{DISCUSSION}

Literature shows that the substances that give pleasant sensations or help the subject in his activity will bring him to repeat the consumption (Duda et al, 1992; Santamaria S., et al 2014; Stella et al 2005). The reported data showed the high consumption of certain drugs ( Striegel H. et al, 2010). Stimulants are used because they increase the ability to concentrate, alertness and safety. They also increase the aggressiveness and the sense of competitiveness. To anabolic are recognized the following effects: euphoria, sense of well being, glee, increased motivation and self-esteem (Mazzeo, 2016). Moreover, the athlete doesn't get bored during the training. Narcotics have a calming effect on the psyche as well as beta-blockers reduce the anxiety and stress. Corticosteroids have, instead, a stimulating effect like alcohol. Moreover, to corticosteroids are recognized: euphoria, increased sociability and sense of well-being. Cannabinoids, such as cannabis, hashish and marijuana, cause changes in mood and perception, euphoria, happiness, relaxation and deep sleep and reducing anxiety. They are considered drug to use social-recreational. (Technische Universität München; Tevis , 2014).

WADA, in 2004, drew up a Code that is constantly emended. The Code explains the definition of doping and contains sanctions too. Others instruments used to contrast doping are the accredited laboratories, the biological passport and the ADAMS (Overbye et al., 2013).

The laboratories have an important role in the discovery of new substances. They also determine the quantitative of those substances, carry out anti-doping tests. Currently, there are 32 laboratories in the World (Table 4) (Valkenburg et. al, 2014).

The Biological Passport is a tool for indirect detection of the presence of a doping substance in biological samples of an athlete. With it, in fact, the changes of certain bio-markers of doping are recorded and 
monitored. If the data, combined with the personal data localization in a given period, exceeded a certain range, the athlete would assume the banned substances (Lippi et al. 2008; Thevis et al, 2014).

The Anti-Doping Administration and Management System (ADAMS) is an on-line database system where are recorded all data: laboratory results, therapeutic use exemptions (TUEs) and information on anti-doping rule violations. It allows the sharing of information amongst the organizations and promotes efficiency, transparency and effectiveness in all anti-doping activities (Møller, et al, 2014).

Table 4. Anti- Doping laboratories in the World

\begin{tabular}{|c|c|c|}
\hline State & City & Note \\
\hline AUSTRALIA & Sydney & \\
\hline AUSTRIA & Seibersdorf & \\
\hline BELGIUM & Ghent & \\
\hline BRAZIL & $\begin{array}{l}\text { Rio de } \\
\text { Janeiro }\end{array}$ & \\
\hline CANADA & Montreal & \\
\hline $\begin{array}{l}\text { PEOPLE'S REPUBLIC } \\
\text { OF CHINA }\end{array}$ & Beijing & \\
\hline COLOMBIA & Bogota & $\begin{array}{l}\text { The WADA accreditation of the Laboratorio de Control al } \\
\text { Dopaje Coldeportes Nacional Bogota - Colombia } \\
\text { was suspended from conducting anti-doping testing for a } \\
\text { period of six months effective } 20 \text { February } 2017 \text {. } \\
\text { Following the expiry of this initial suspension period, the } \\
\text { laboratory's suspension was extended for an } \\
\text { additional period of up to six months to address outstanding } \\
\text { non-compliances. }\end{array}$ \\
\hline CUBA & Havana & \\
\hline FINLAND & Helsinki & \\
\hline FRANCE & Paris & \\
\hline GERMANY & $\begin{array}{l}\text { Cologne } \\
\text { Kreischa }\end{array}$ & \\
\hline GREAT BRITAIN & London & \\
\hline GREECE & Athens & \\
\hline INDIA & New Delhi & \\
\hline ITALY & Roma & \\
\hline JAPAN & Tokyo & \\
\hline KOREA & Seoul & \\
\hline MEXICO & Mexico & $\begin{array}{l}\text { The WADA accreditation of the Laboratorio Nacional de } \\
\text { Prevencion y Control del Dopaje-CONADE, Mexico } \\
\text { was suspended from conducting anti-doping testing for a } \\
\text { period of six months effective } 23 \text { November } 2016 \text {. } \\
\text { Following the expiry of this initial suspension period, the } \\
\text { laboratory's suspension was extended for an } \\
\text { additional period of up to six months to address outstanding } \\
\text { non-compliances. }\end{array}$ \\
\hline NORWAY & Oslo & \\
\hline POLAND & Warsaw & \\
\hline
\end{tabular}




\begin{tabular}{lll}
\hline PORTUGAL & Lisbon & $\begin{array}{l}\text { suspended from conducting anti-doping testing for an } \\
\text { undetermined period effective as of 15, April 2016. }\end{array}$ \\
QATAR & Doha & \\
ROMANIA & Bucharest & \\
SPAIN & Barcelona & suspended from conducting anti-doping testing for an \\
& Madrid & $\begin{array}{l}\text { undetermined period effective as of 6, June 2016. } \\
\text { SWEDEN }\end{array}$ \\
SWITZERLAND & Stockholm & \\
THAILAND & Lausanne \\
TURKEY & Bangkok \\
UNITED STATES & Ankara \\
& Los Angeles \\
& Salt Lake \\
& City \\
\hline
\end{tabular}

\section{CONCLUSIONS}

Doping is a phenomenon characterized by clandestineness (Mazzeo et al. 2016). The anti-doping tests provide insufficient data for statistical extrapolations and accurate estimates of the phenomenon, because of the small number of athletes tested and the imprecision of the methods of research (Sadeghi Pour, et al., 2009). The lack of statistical significance is due precisely to the low sampling of the tests, compared to tens of millions of athletes engaged in sports practices also outside of the vertices competitive (Ferrara, 2004).

Athletes subject to Italian and WORLD drug antidoping testing may be subject to both in- and out-ofcompetition testing. At the present, the tests are based on urine samples (Mazzeo et al, 2018). Blood tests should enable verification of the level of haematocrit or haemoglobin. This type of analyses based on more specific parameters (direct or indirect) could well reveal forms of doping that cannot be detected in urine (de Mérode et. al, 1999).

To confirm what said up to now, on April 2006, DOXA Institute submitted 508 athletes to an anonymous questionnaire about beliefs on and attitude on doping of Italian athletes. They "confessed" that the tests are infrequently and poorly effective and they should be more frequent and follow a different protocol (Tavani et al., 2012).

Inappropriately, today, although the technological advancement that characterizes the field of scientific research, the analytical methods are not sufficiently dependable for the search of the complete group of substances included in the anti-doping lists (Mazzeo et al., 2016).

Another inquiry is the great difficulty to anticipate the moves of the opponent and this, therefore, is not easy to understand what new substances will be taken and what new methods will be adopted (Ministero della Salute 2013). Anyway, close collaboration among the accredited laboratories would enable them to keep up to date and exchange new techniques. Closer ties with the pharmaceutical industry and those involved in basic research are also vital if they are to be able to anticipate new tendencies and forms of doping by means of a sort of scientific "vigil" (Marcley et al, 20. The instrumentation and measurements industry would also be able to give them the benefit of recent progress in their domain (de Mérode, et al. 1999). 
Furthermore, the purposes of the World Anti-Doping Program and the Code are to protect the athlete's fundamental right to participate in doping-free sport and thus promoting health, fairness and equality for athletes world wide. Potentially risks to health by doping are taken in the pursuit of sporting excellence (Mazzeo, et. al., 2015) . The increasing profile of sport for athletes with a disability, and its potential rewards, has led some athletes to seek improved performance through the administration of prohibited substances.

Moreover, is essential for economic and social development that the health sector is responsible for: developing and implementing national and subnational health strategies (Mazzeo, 2016).

\section{REFERENCES}

Altavilla, G., Riela, L., Di Tore, A.P., Raiola, G. (2017) The physical effort required from professional football players in different playing positions, Journal of Physical Education and Sport, 17 (3), art. no. 200, pp. 2007-2012.

Badoud F., Guillarme D., Boccard J., Grata E., Saugy M., Rudaz S. and Veuthey J-L. (2011) "Analytical aspect in doping control: Challenges and perspectives", Forensic Science International, 2013, 4961. https://doi.org/10.1016/i.forsciint.2011.07.024

Botrè F. (2008) "New and old challenges of sport drug testing", J. Mass Spectrom,; 43, 903-7. https://doi.org/10.1002/jms.1455

Calatayud VA, Alcaide GG, Zurian JC and Benavent RA..(2007) "Consumption of anabolic steroids in sport, physical activity and as a drug of abuse: an analysis of the scientific literature and areas of research", Br J Sports Med; 42: 103-9. ISSN 14730480.

D'Isanto, T. (2016) Pedagogical value of the body and physical activity in childhood [Pedagoška vrijednost tijela i tjelesne aktivnosti u djetinjstvu] Sport Science, 9, pp. 13-18.

Dvorak J., Baume N., Botré F., Broséus J., Budgett R., Frey WO., Geyer H. et al. (2014) "Time for change: a roadmap to guide the implementation of the World Anti Doping Code 2015", Br J Sport Med, 0, 16. https://doi.org/10.1136/bjsports-2014-093561

Dilger A., Frick B. and Tolsdorf F. (2007) "Are athletes doped? some theoretical arguments and empirical evidence", Contemporary Economic Policy, 25 (4), 604-615. https://doi.org/10.1111/j.14657287.2007.00076.x

Duda J. L. and Nicholls J.C. (1992) "Dimension of Archievement Motivation in Schoolwork ant Sport", Journal of Educational Psychology, 84, 3, 290-99. ISSN 00220663.

Esseiva P., loset S., Anglada F., Gaste L., Ribaux O., Margot P. Gallusser A., Biedermann A., Specht Y. and Ottinger E. (2007) "Forensic drug intelligence: an important toll in law enforcement", Forensic Sci. Int., 16: 247-54. https://doi.org/10.1016/j.forsciint.2006.06.032

Kayser B., Mauron A. and Miah A., 2005, "Viewpoint: Legalisation of Perfomance-Enhancing Drugs", The Lancet, 366, S21. https://doi.org/10.1016/S0140-6736(05)67831-2

Marclay F., Mangin P., Margot P. and Saugy M. (2012) "Perscpetcives for Forensic Intelligence in antidoping: Thinking outside of the box", Forensic Science International, (229) 133-144. https://doi.org/10.1016/j.forsciint.2013.04.009

Lippi G., Banfi G., Franchini M., and Guidi GC. (2008) "New strategies for doping control", J Sports Sci; 26(5), 441-5. https://doi.org/10.1080/02640410701624556

Martínez-Sanz, J.M.; Sospedra, I.; Ortiz, C.M.; Baladía, E.; Gil-Izquierdo, A.; Ortiz-Moncada, R. (2017) Intended or Unintended Doping? A Review of the Presence of Doping Substances in Dietary Supplements Used in Sports. Nutrients, 9, 1093.Mazzeo, F., Monda, M., Messina, G., Mazzeo, F. (2016). Current concept of obesity. Sport Science, 9(2), 42-48. 
Mazzeo, F., Santamaria, S., Monda, V., Tafuri, D., Dalia, C., Varriale, L., . . Monda, M. (2016). Dietary supplements use in competitive and non-competitive boxer: An exploratory study. Biology and Medicine, 8(4). https://doi.org/10.4172/0974-8369.1000294

Mazzeo, F. (2016). Drug abuse in elite athletes: Doping in sports. Sport Science, 9 (2): 34-41.

Mazzeo, F., Santamaria, S., \& lavarone, A. (2015). "Boosting" in paralympic athletes with spinal cord injury: Doping without drugs. Functional Neurology, 30 (2), 91-98. https://doi.org/10.11138/FNeur/2015.30.2.091

Mazzeo, F., \& Volpe, R. A. (2016). From gene doping to athlete biological passport. Sport Science, 9 (2), 97-103.

Montesano, P., Tafuri, D., Esposito, A., Gigante, F., Salzano, E., Viscido, G., \& Mazzeo, F. (2013). Conditional abilities in young special olympics athletes who practice unified football. Journal of Physical Education and Sport, 13(4), 504-510. https://doi.org/10.7752/ipes.2013.04079

Mazzeo F., Monda V., Santamaria S., et. al., (2018) Antidoping program promotes and protects the integrity of sport and athlete's health, The Journal of Sports Medicine and Physical Fitness, July.

Møller V. and Dimeo P. (2014) "Anti-doping - the end of sport", International Journal of Sport Policy and Politics, , 6(2) 259-272. https://doi.org/10.1080/19406940.2013.798740

Ministero della Salute (2013) Reporting System Doping Antidoping, from: http://www.salute.gov.titimgs/C_17_pubblicazioni_2171_ulterioriallegati_ulterioreallegato_0_alleg.p df

Raiola, G. (2017) Motor learning and teaching method, Journal of Physical Education and Sport, 17, art. no. 236, pp. 2239-2243.

Raiola, G., \& D'Isanto, T. (2017). Assessment of periodization training in soccer. Journal of Human Sport and Exercise, 11(1 proc), S267-S278. https://doi.org/10.14198/ihse.2016.11.Proc1.19

M., Knudsen M. L. and Pfister G. (2013). "To dope or not to dope: Elite athletes' perceprions of doping deterrents and incentive", Performace Enhancement \& Health, 2, 119-134. https://doi.org/10.1016/i.peh.2013.07.001

Valkenburg D, de Hon O, van Hilvoorde I (2014). Doping control, providing whereabouts and the importance of privacy for elite athletes. Int J Drug Policy. (2014) Mar;25(2):212-8. https://doi.org/10.1016/i.drugpo.2013.12.013

Sadeghi Pour H.R., Rahnama N., Bambaeichi E., Naderian M., Saltan Hosseini M. and Abedinzadeh S., (2009) "Statistics Related to doping and Type of Doping Drugs in Universal Sport", World J of Sport Sci, 2(3): 184-189. ISSN: 2078-4724.

Santamaria, S., Messina, A., Montesano, M., ... Tafuri, D. (2016). Doping in Italy: An analysis of its spread in ten years. Biology and Medicine, 8(1) doi:10.4172/0974-8369.1000263Technische Universität München. From: http://www.doping-prevention.sp.tum.de/it/doping-prevention.html

Santamaria S. and Mazzeo F., (2014) "Ethical issues and doping in Olympic and Paralympic Games", Medicina Sportiva, X (4), 2411-2417. ISSN 1841-0162.

Thevis M. and Scänzer W. (2014). "Analytical approaches for the detection of emerging therapeutics and non -approved drugs in human doping controls", J. Pharm Biomed Anal, 101, 66-83. https://doi.org/10.1016/i.jpba.2014.05.020

Stella, L., D'ambra, C., Mazzeo, F., Capuano, A., Del Franco, F., Avolio, A., \& Ambrosino, F. (2005). Naltrexone plus benzodiazepine aids abstinence in opioid-dependent patients. Life Sciences, 77(21), 2717-2722. https://doi.org/10.1016/j.lfs.2005.05.036

Strano Rossi S. and Botrè F., (2011) "Prevalence of illicit drug use among the Italian athlete population with special attention on drugs of abuse: A -10 year review", J. Sports Sci, 29 (5): 471-6. https://doi.org/10.1080/02640414.2010.543915 
Striegel H, Ulrich R and Simon P., 2010, "Randomized response estimates for doping and illicit drug use in elite athletes", Drug Alcohol Depend.,106(2-3), 230-2. https://doi.org/10.1016/i.drugalcdep.2009.07.026

Sjöqvist F., Garle M. and Rane A., 2(008) "Use of doping agents, particularly anabolic steroids, in sports and society", Lancet, 31, 371(9627): 1872-82. https://doi.org/10.1016/S0140-6736(08)60801-6

Tavani A., Colombo P., Scarpino V., Zuccaro P., Pacifici R. and La Vecchia C. (2012) "Beliefs on and attitude toward doping use among athletes: an Italian Survey", IJPH, 9 (4), e8669-1 - 7, doi: $10.2427 / 8669$

Tiziana, D., Antonetta, M., Gaetano, A. (2017) Health and physical activity [Zdravlje i tjelesna aktivnost], Sport Science, 10 (1), pp. 100-105.

Valkenburg D., de Hon O. and van Hilvoorde I., (2014) "Doping control, providing whereabouts and the importance of privacy for elite athletes", Int. J. Drug Policy, 25, 212-8. https://doi.org/10.1016/j.drugpo.2013.12.013

World Anti-Doping Agency, 2017, "List of WADA accredited laboratories", from https://www.wadaama.org/en/resources/laboratories/list-of-wada-accredited-laboratories. 